\title{
EDUCATION ON HEALTHY EATING IMPROVED NUTRITION-RELATED PRACTICES IN POLISH PRESCHOOLS
}

\section{EDUKACJA NA TEMAT PRAWIDLOWEGO ŻYWIENIA POPRAWIŁA PRAKTYKI ZWIĄZANE Z REALIZACJĄ ŻYWIENIA W PRZEDSZKOLACH W POLSCE}

\author{
Joanna Myszkowska-Ryciak ${ }^{1(\mathrm{~A}, \mathrm{~B}, \mathrm{C}, \mathrm{D}, \mathrm{E}, \mathrm{F})}$, Anna Harton ${ }^{1(\mathrm{~A}, \mathrm{~B}, \mathrm{C}, \mathrm{D})}$
}

\author{
${ }^{1}$ Warsaw University of Life Sciences, Poland
}

Authors' contribution Wkład autorów: A. Study design/planning zaplanowanie badań B. Data collection/entry zebranie danych C. Data analysis/statistics dane - analiza i statystyki D. Data interpretation interpretacja danych E. Preparation of manuscript przygotowanie artykułu F. Literature analysis/search wyszukiwanie i analiza literatury G. Funds collection zebranie funduszy
Tables: 0

Figures: 6

References: 30

Submitted: 2017 Dec 18

Accepted: 2018 May 10

\section{Summary}

Background. Improving the nutritional knowledge of the preschool staff responsible for nutrition can translate into better quality menus served to children. The purpose of the present study was to evaluate the effects of a nutrition education program in participating preschools. As criteria for evaluation of the program, changes in selected nutritional practices reported by the institutions' staff as well as their opinion on the program were analyzed.

Material and methods. The research consisted primarily of a survey, performed in 2015 and repeated in 2016 in randomly selected preschools participating in the program "Eating healthy, growing healthy" in Poland. In 2015, 66 institutions were included in the survey, and in 2016, 138 preschools were included. In both, the CATI method was used for data collection, and data were collected by specially trained interviewers. Respondents were asked about selected nutrition-related practices in the institution (e.g. usage of salt/sugar, water availability, meal presentation). They also evaluated the suitability of the program for diet planning in the preschool setting.

Results. Preschool managers evaluated the project very highly in terms of value and usefulness of the content in their daily practice. The program has brought results in changing nutrition practices: salt and sugar in the children's meals were reduced, water availability was increased, and menus were adapted to current nutritional recommendations. The high evaluation of the program increased the reported interest in participating in similar programs in the future, however, it did not translate into a greater willingness to include paid "healthy eating" workshops in the institutions.

Conclusions. Nutrition education improved the quality of nutrition in preschools, but in order to reach a wide range of institutions, it is necessary to focus on the implementation of free-ofcharge educational programs.

Keywords: education, nutrition, children, preschools

\section{Streszczenie}

Wprowadzenie. Wiedza żywieniowa personelu odpowiedzialnego za żywienie dzieci w placówkach może przekładać się na lepszą jakość oferowanych w przedszkolach jadłospisów. Celem pracy była ocena efektów programu edukacyjnego w zakresie żywienia w uczestniczących przedszkolach. Jako kryteria oceny uwzględniono zmiany w wybranych praktykach żywieniowych deklarowane przez personel instytucji, a także ich opinię na temat programu.

Materiał i metody. Badanie przeprowadzono w 2015 r. i powtórzono w 2016 r. w losowo wybranych przedszkolach uczestniczących w programie edukacyjnym „Zdrowo jemy, zdrowo rośniemy" w Polsce. W 2015 r. w badaniu wzięło udział 66 instytucji, a w 2016 r. 138 przedszkoli. Dane zostały zebrane przez specjalnie przeszkolonych ankieterów metodą CATI. Respondentów zapytano o wybrane praktyki związane $\mathrm{z}$ żywieniem $\mathrm{w}$ instytucjach (np. stosowanie soli/cukru, dostępność wody, prezentację posiłków). Respondenci ocenili także przydatność programu w planowaniu diety w placówkach przedszkolnych.

Wyniki. Pracownicy przedszkoli bardzo wysoko oceniali projekt pod względem merytorycznym oraz przydatności informacji w codziennej praktyce. Program przyczynił się do poprawy praktyk żywieniowych: redukcji soli i cukru w posiłkach dla dzieci, większej dostępności wody i dostosowaniu jadłospisów do aktualnych zaleceń żywieniowych. Wysoka ocena programu zwiększyła deklarowane zainteresowanie uczestnictwem w podobnych programach w przyszłości. Nie przełożyło się to jednak na większą gotowość do uczestniczenia w płatnej edukacji na temat zdrowego żywienia.

Wnioski. Edukacja żywieniowa poprawiła jakość żywienia w przedszkolach. Jednak, aby dotrzeć do szerokiej rzeszy placówek wychowania przedszkolnego, konieczne jest wprowadzenie bezpłatnych programów edukacyjnych.

Słowa kluczowe: edukacja, żywienie, dzieci, przedszkola

Myszkowska-Ryciak J, Harton A. Education on healthy eating improved nutrition-related practices in Polish preschools. Health Prob Civil. 2018; 12(4): 238-246. https://doi.org/10.5114/hpc.2018.79986

Address for correspondence / Adres korespondencyjny: Joanna Myszkowska-Ryciak, Department of Dietetics, Warsaw University of Life Sciences, Nowoursynowska 159C, 02-776 Warsaw, Poland, e-mail: joanna_myszkowska_ryciak@sggw.pl, phone: +48 225937022

ORCID: Joanna Myszkowska-Ryciak https://orcid.org/0000-0001-7167-1993, Anna Harton https://orcid.org/0000-0001-5805-6996

Copyright: (C) Pope John Paul II State School of Higher Education in Biała Podlaska, Joanna Myszkowska-Ryciak, Anna Harton. This is an Open Access journal, all articles are distributed under the terms of the Creative Commons Attribution-NonCommercial-ShareAlike 4.0 International (CC BY-NC-SA 4.0) License (http:// creativecommons.org/licenses/by-nc-sa/4.0/), allowing third parties to copy and redistribute the material in any medium or format and to remix, transform, and build upon the material, provided the original work is properly cited and states its license. 


\section{Introduction}

In the widespread epidemic of overweight and obesity, appropriate nutrition during the stage of growth and development is particularly important. Excess body mass in childhood translates into an increased risk of obesity in adulthood [1, 2]. In addition, eating habits are developed in childhood, and this translates into nutritional choices in adulthood. At the age of 3-5 years, the child's diet is still largely dependent on the parents, but the child's external environment is becoming more and more influential [3]. This is particularly pronounced in children attending preschool. In this institution, the child spends up to 10 hours a day and consumes at least 3 meals, which include up to $75 \%$ of the daily energy and nutrient intake [4]. This makes preschool an ideal setting for the promotion of healthy eating [5].

In Poland in 2015-2016 over 1.1 million children aged 3-5 years attended more than 21000 preschool day care centers (DCCs) [6]. Adequate nutrition in these institutions is therefore crucial for the proper nutritional status of the pediatric population aged 3-5 years old in Poland. In this aspect, nutrition education is essential to increase knowledge and awareness of the correct composition of children meals, especially in terms of the adequate amount of vegetables, fruits, milk and milk products, and reduction of sugar and salt intake [4, 7, 8, 9]. Such educational actions should be first directed to parents/caregivers, as they decide on the child's diet. But this education also needs to include others, especially those who have an impact on diet planning, i.e. staff of childcare facilities $[7,8]$. To be effective, educational activities should be always conducted by specially trained experts, have a broad range, and have consistent goals and scope.

An example of a nationwide nutritional education project implemented in kindergartens is the program "Mom, Dad, I prefer water!" which was initiated by Żywiec Zdrój S.A. in 2009 [10]. Its aim is to highlight the role of water in the daily diet, to draw attention to the issue of environmental protection, and to support in the development of healthy eating habits in children. Despite the long implementation period and nationwide coverage, there are no scientific publications assessing its effectiveness. Another example of an educational program directed both to preschool children and their parents is "Correct child nutrition and adult person health" conducted in 6 preschools in Cracow in 2006 [11]. In this program children participated in workshops on the acceptance of fresh fruits and vegetables, and parents were educated on the correlations between childhood nutrition and the development of select lifestyle diseases. However, this program also lacks information on its effectiveness, i.e. its impact on the consumption of fruits and vegetables by children or their presence in preschool menus.

"Eating healthy, growing healthy" (EHGH) is a unique, comprehensive educational program initiated by the Nutricia Foundation, whose main purpose was to promote the principles of proper nutrition in nurseries and preschools and to develop proper nutritional habits among children [12]. DCC staff, parents and caregivers of children received nutrition education from specially trained educators - nutritionists and specialists in the field of dietetics, human nutrition and health promotion. The educational activities included lectures, consultations and nutrition workshops, which were free-of-charge for participating institutions. In total, 2638 institutions (including nurseries, preschools, and other types of DCCs for children aged 0.5-6 years old throughout Poland) participated in the program, of which 1347 were directly involved. 13,214 employees of these institutions were educated directly. To maintain a high level of quality in the program, nutrition education was provided by specially trained professionals. Within the program, 170 graduates of dietetics or human nutrition completed a 24-hour nutrition training, preparing them for the role of nutrition educators. Afterwards, educators passed through a 6-month internship in DCCs, involving a series of workshops for staff (free of charge) on topics related to healthy diet and planning and preparing meals for children. The overview of the project EHGH is presented in Figure 1 and described in a previous paper [13]. 


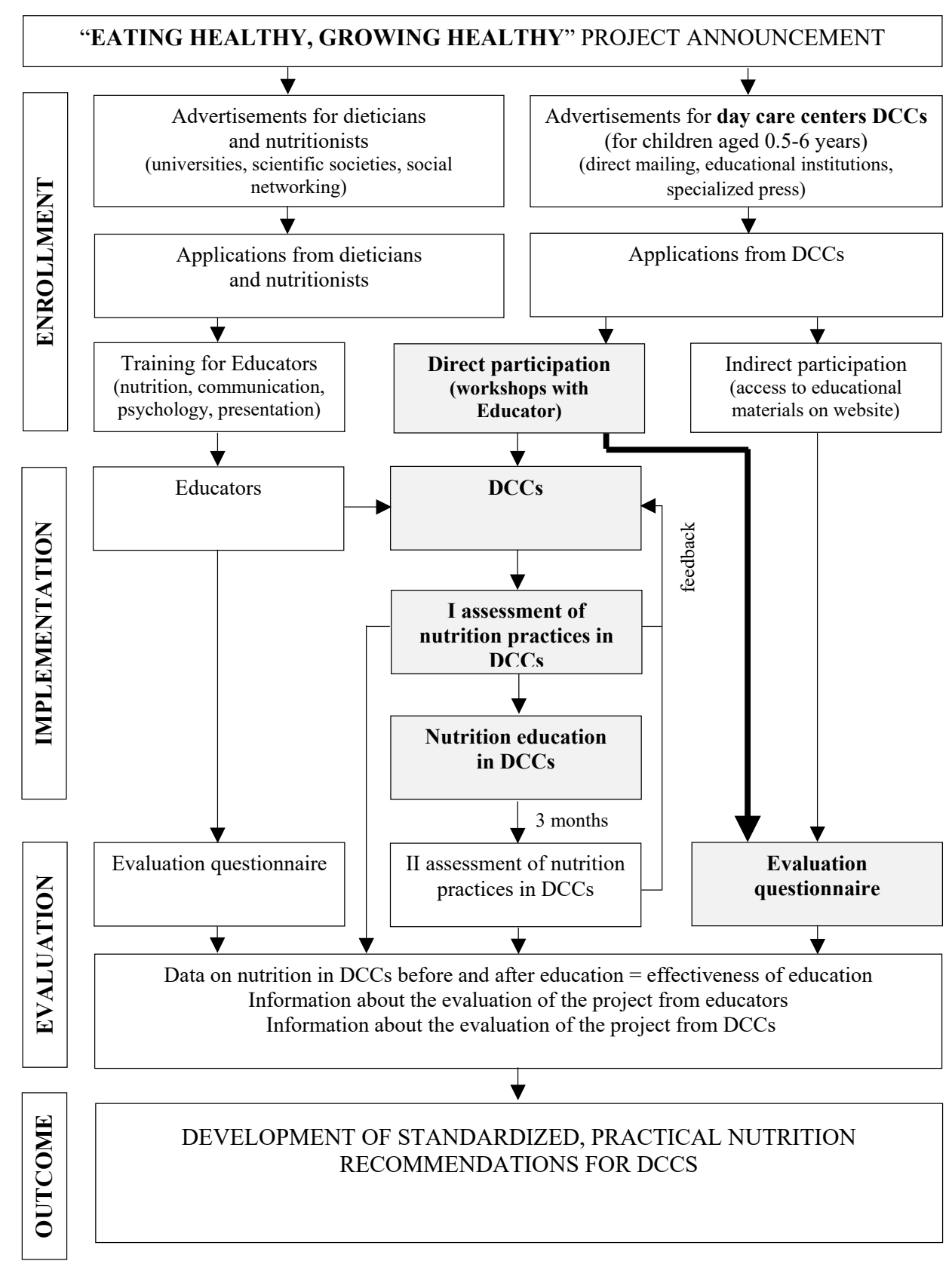

Figure 1. The overview of the program "Eating healthy, growing healthy". The program stages discussed in this article are highlighted in gray

The purpose of the present study was to evaluate the effects of a nutrition education program in participating preschools. The criteria for evaluation were changes in selected nutritional practices according to the institutions' staff, as well as their opinion on the program.

\section{Material and methods}

The first survey was conducted in May and June 2015 and the second in November 2016. They included randomly selected preschools in Poland which took part in the program "Eating healthy, growing healthy". The aim of the program was to improve the nutrition of children in day care centers through nutritional education of the staff conducted by specially trained educators. Evaluation of the effectiveness of education was an important part of the project. The chosen criteria for evaluation were changes in selected nutritional practices as reported by the institutions' staff and the staff's opinion of the program. To accomplish this evaluation, 66 preschools were randomly selected from the total group of preschools which finished the education program for the survey in 
2015, and 138 preschools were randomly selected due to the larger number of participating institutions in 2016. The CATI (Computer-Assisted Telephone Interviewing) method was used. Phone interviews were conducted with DCC managers and data was collected by specially-trained interviewers. The main goal of the research was to determine the effects of the above-described educational program on selected aspects of nutrition in participating institutions. Additionally, the survey was intended to obtain information on the usefulness of the knowledge provided within the program, and the willingness to participate in similar programs in the future. Respondents were asked about selected nutrition-related practices in institutions that have gone through the training program (e.g. usage of salt/sugar, water availability, meal presentation), as well as their opinion of the suitability of the program in diet planning.

This article focuses on the evaluation of the program by the managers of preschools (directors or manciple officers), including the evaluation of nutrition education and the reported changes in selected nutrition-related practices.

\section{Results}

Preschool staff highly appreciated the value of the training provided within the program. In 2016, 80\% of respondents appraised the merits of the program as very good, compared to $61 \%$ in 2015 . Within these two surveys only two respondents expressed a negative opinion about the content of the program (in 2016). This assessment was reflected in the reported high frequency of use of acquired knowledge in everyday practice in DCC. It is worth emphasizing that the following year of the program had an increased number of surveyed staff that described the use of the acquired information in daily practice as "very good." Within two years of the program's beginning, only 6 of 204 respondents found the acquired knowledge was not practical enough to affect the nutrition of children in their institution (Fig. 2).

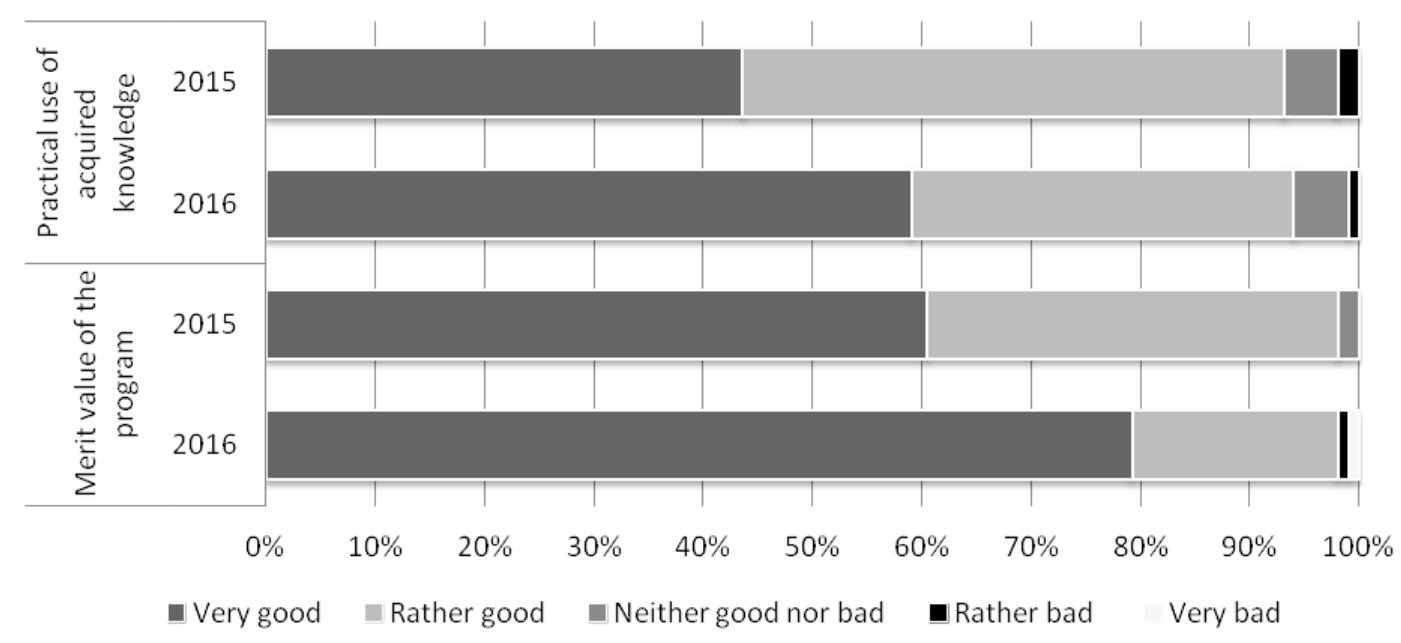

Figure 2. The evaluation of the value of the program and the practical application of acquired knowledge in every day practice by preschool staff

Within the program, free workshops with a variety of nutritional topics addressing important and critical aspects of children's nutrition were offered to the institutions. Each facility participating in the program could select the most desired topics based on its needs and knowledge of its staff. The topics of workshops chosen by the institutions are shown in Figure 3. 


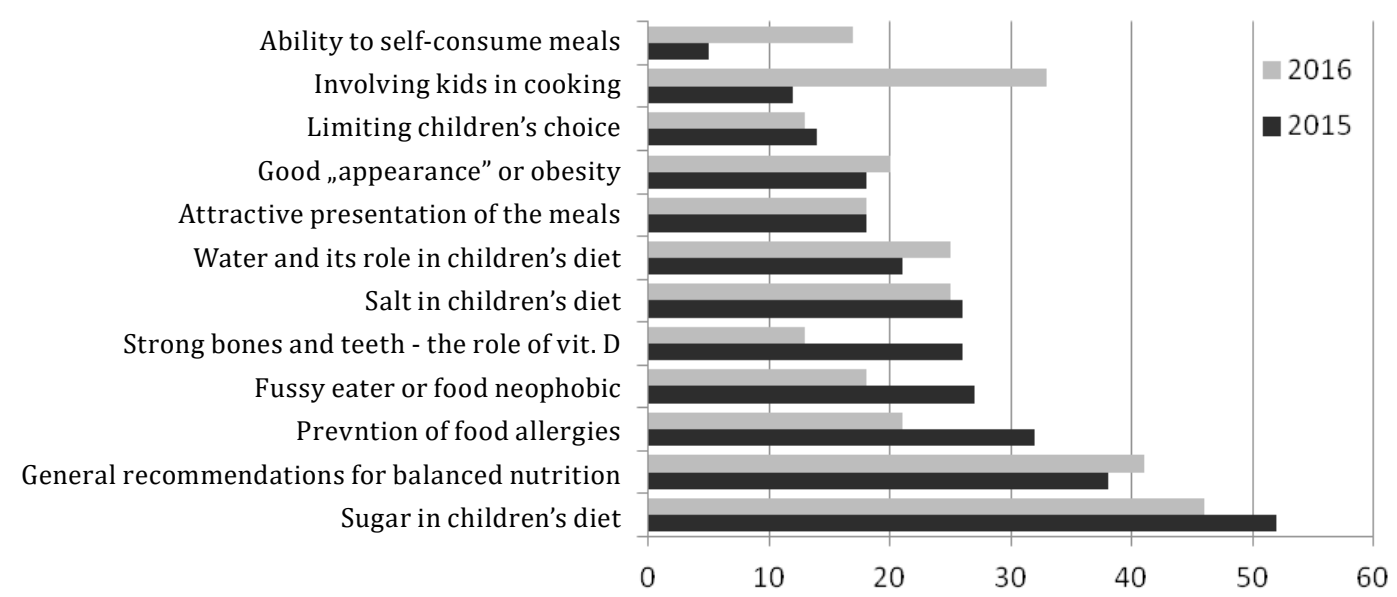

Figure 3. Interest in particular topics of the workshops reported by the respondents (\%)

The workshops about sugar in children's diet were the most often chosen by preschools, both in 2015 and 2016. The second most frequent choice was the workshop on general recommendations for a balanced diet. In 2015 the third choice was the topic of prevention of food allergies, whereas in 2016 it was methods of involving children in preparing meals. Interestingly, in 2016 there was an almost three-fold increased interest in the workshop supporting the ability of children to consume meals by themselves.

Participation in the program was expected to contribute to changes in the nutrition of children in institutions. Changes in selected nutrition-related practices in kindergartens reported by respondents are presented in Figure 4.

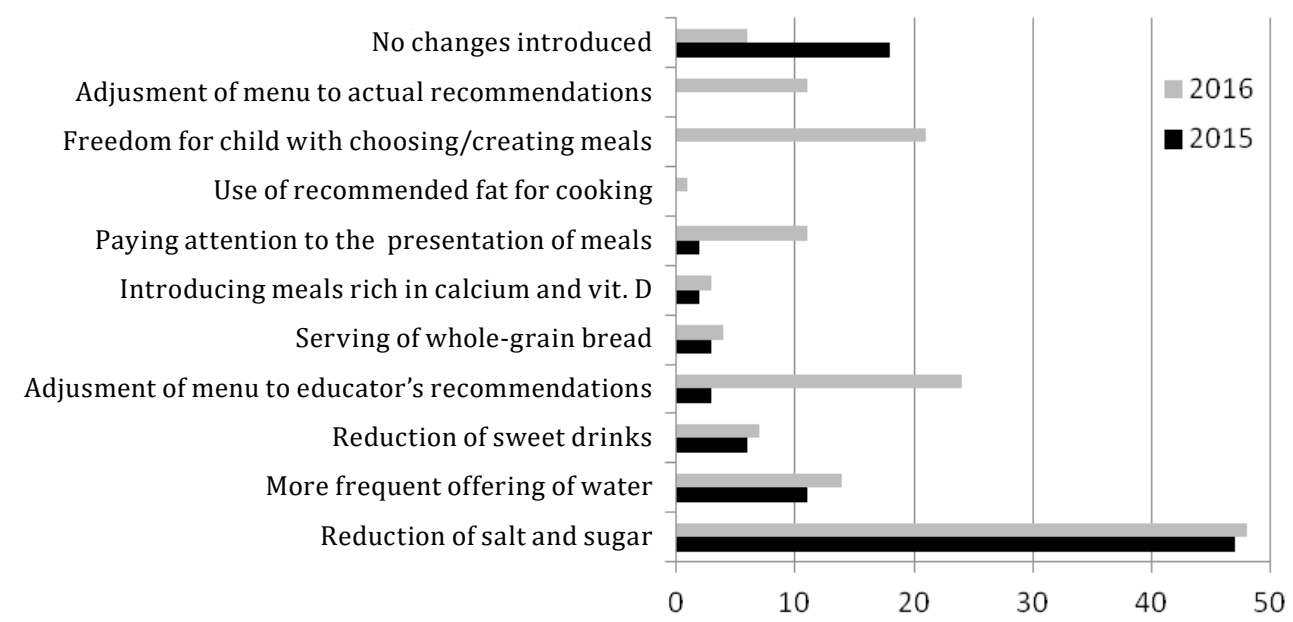

Figure 4. Changes in nutrition-related practices caused by education as reported by preschool staff (\%)

Most respondents reported a decrease in sugar and salt in children's food and increased availability of water. In 2016 every fourth respondent reported adjustments in the menu suggested by the educator, and more than $20 \%$ allowed greater freedom for children in choosing/creating their meals. It is worth pointing out that the number of respondents who reported no change decreased by 3 times in 2016 compared to 2015.

The survey was lengthened in 2016 and respondents were asked to identify the most attractive part of the program. Nearly half of the respondents most appreciated support in creating correct eating habits in children, and $28 \%$ appreciated the various forms of cooperation. A similar number of respondents considered as most important the no-cost training and transferred nutritional knowledge (Fig. 5). 


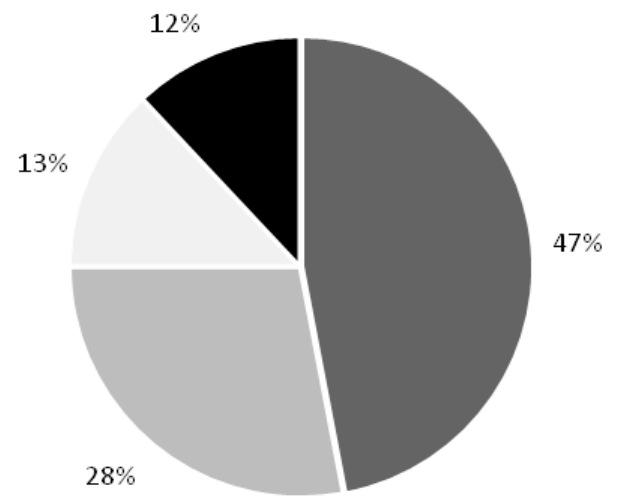
- Support in creating correct eating habits among the kids
-Variety of activities (workshops, analysis of the decade menu)

Free-of-charge

- Scope of knowledge transfer

Figure 5. The most important elements of the program in the respondents' opinion (\%)

Declared interest in attending similar programs and willingness to include paid nutrition workshops in the educational offerings of the institution are presented in Figure 6.

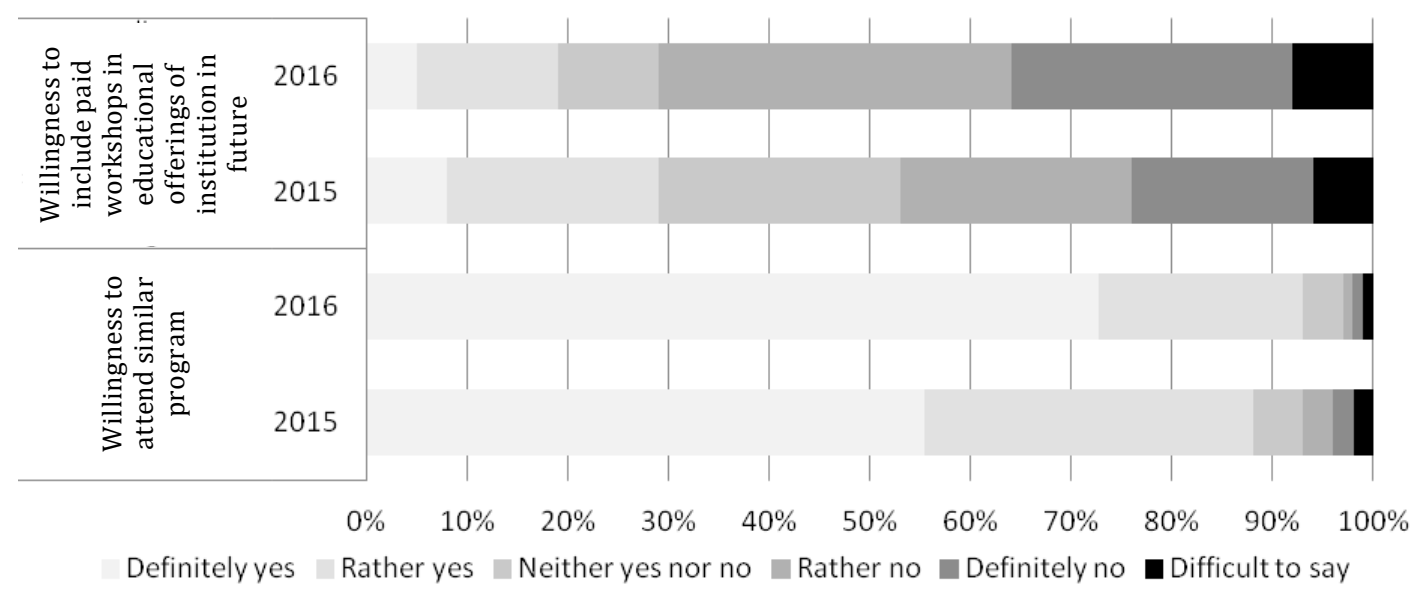

Figure 6. Declared interest in attending in similar programs and willingness to include paid nutrition education in the educational offerings of the institution

In 2015, over half of the respondents expressed their strong willingness to participate in a similar program in the future. In 2016, the number of such responses increased to almost three quarters. At the same time, the number of negative responses decreased to less than half of the first year. Despite the generally declared willingness to participate in similar programs, a small number of respondents were inclined to include paid "healthy eating" workshops in the preschool education program. In $201541 \%$ of respondents reported no such desire, and in 2016 this number increased to $63 \%$. Among the reasons for this were listed: lack of funds for such activities (78\%), no need for such activities (7\%), and others (15\%).

In 2016, respondents were also asked to identify groups to whom similar programs should be directed in the future. According to the respondents, such programs in future should focus on parents $(64 \%)$ followed by children (30\%). The respondents listed staff from institutions in third place (22\%).

\section{Discussion}

Preschoolers are more likely than teenagers to be influenced by parents and caregivers in an eating environment [14]. Among the social factors within the childcare environment, caregivers' feeding practices were strongly connected with children's dietary intake [15]. Therefore, pre-school educators can significantly shape children's eating habits, and should be a primary focus for obesity prevention programs in this age group. The American Academy of Nutrition and Dietetics recommends that preschool caregivers be a role model for children and encourage healthy eating, support children's hunger and satiety cues, serve family style meals, and not force children to eat [7]. However, for such activities, nutritional knowledge and awareness of nutritional risk factors for diet-related diseases are essential. This is especially important in the absence of precise legal regulations 
covering the principles of nutrition in institutions. In Poland, by the $1^{\text {st }}$ September 2015 there was no mandatory law regulating nutrition in kindergartens. Since then, the Minister of Health introduced a regulation, which defined exactly what foods products could be used for children's nutrition, reduced sugar and salt, and defined the number of portions of vegetables, fruits, dairy products and fish in DCCs menus [16]. Unfortunately, due to the lack of relevant information and an education campaign, the regulation met with great social criticism and was repealed after a year. The current regulations are very general and allow great flexibility in planning child feeding [17]. Therefore, nutrition education for kindergarten staff in Poland is crucial, and should be conducted systematically and on a large scale.

The worldwide problem of excessive body weight also affects Poland, including young children [18]. In preventing obesity, it is very important to limit the sugar content as well as to serve drinking water instead of sweetened drinks $[19,20,21]$. Workshops on these topics were offered within our educational program and were very often chosen by the institution. This may indicate that despite the high availability of professional literature on the topic [21], institutions need specialist support. Frequent reports of sugar restriction, and the introduction of water by respondents can be considered a result of the workshops and demonstrate the success of the program.

In preventing obesity, the key is energy balance, which is associated with self-regulation of food consumption. American Academy of Nutrition and Dietetics recommends that childcare providers help children to understand their feelings of hunger and satiety. Preschool educators can support children in recognizing their feelings of hunger and satiety by using verbal comments during the meal (e.g., "Are you full?") to draw children's attention to their internal signals of hunger and satiety [22]. Developing training for preschool caregivers that focuses on using verbal comments during meal times to get children to understand their hunger and satiety is a viable and inexpensive approach that may help children self-regulate their dietary intake [23]. A similar effect has been observed with food and beverages served in family style, where children can decide on their own portion size and serve themselves [7]. It is worth emphasizing that interest in these topics increased in 2016, and more respondents reported changes in this direction, as well as involving children in meal preparation.

The next important topic that was presented as an educational offering of the program was calcium and vitamin D deficiencies. Irregularities in this area are very often observed in different age groups, including preschool children $[24,25]$. This situation may result from irregularities at the planning stage of preschool menus [26], which might be improved by education [27, 28].

It is worth emphasizing that both the thematic scope and the practical application of the information obtained were very well appreciated by the respondents. These results tended to increase in 2016. Many institutions have reported that they completed changes suggested by the educator, and have particularly appreciated help in shaping correct eating habits in children. Such a high rating by the respondents could have resulted from very good educational preparation of the educators. It is worth mentioning that the training included not only nutritional information, but also methods of effective communication with different recipients.

This study has some limitations. Data collection was limited to a technically possible test sample. The data collected during interviews with staff were self-reported (not observational), which might have led to response bias. It will be possible to make a conclusion about the effectiveness of the program after its completion. The qualitative and quantitative evaluation of the institutions' menus before and after nutrition workshops has been planned for objective evaluation of program results. At present, based on the data presented in this paper and preliminary observations $[27,28]$ we can assume that nutrition education has a positive impact on improving the quality of feeding in preschools. The other authors also point to the need for nutrition education addressed to the personnel of childcare institutions $[24,25,29,30]$.

\section{Conclusions}

The program "Eating healthy, growing healthy" has been evaluated positively by respondents. Compared to data from 2015, the program evaluation in 2016 was even better in many aspects. And most importantly, results showed that the educational form of the project has brought real results in changing nutrition-related practices in DCCs, particularly in areas such as: limiting salt and sugar in meals prepared for children, offering water more frequently, and adapting the menu to the actual nutritional recommendations. The respondents of the surveyed preschools also declared that greater attention is paid to the presentation of meals prepared for children as well as to children's freedom of food selection and portion size. The institutions were aware of the need for similar programs directed not only to staff members but primarily to parents, and later children.

The good appraisal of the program and the practical results of the education increased interest in similar programs in the future. However, this increase in interest did not translate into a greater willingness to include 
paid healthy eating workshops in the educational offerings of the institutions. The idea of including such activities has only been moderately accepted, not because of the content's merit, but because of the lack of funds for such a project. In planning similar programs, it is worth considering the possibility of obtaining external funds. It seems that only through free educational programs can a wide range of institutions be reached. It is worth stressing that proper nutrition of children must be treated as an investment in their healthy development, and there is an urgent need for a systematic solution to improve nutrition in preschools.

\section{Acknowledgments}

This research was financed by Danone Ecosysteme research and education grant within the program "Eating healthy, growing healthy". The authors of this publication want to express their gratitude to the Nutricia Foundation and partners of "Eating healthy, growing healthy" program: The Comenius Foundation for Child Development, The Institute of Mother and Child, The Academic Business Incubators and Educators involved in the project.

Conflicts of Interest: The authors declare no conflict of interest. The founding sponsors had no role in the design of the study; in the collection, analyses, or interpretation of data; in the writing of the manuscript, or in the decision to publish the results.

\section{References:}

1. Ogden CL, Carroll MD, Kit BK, Flegal KM. Prevalence of obesity and trends in body mass index among US children and adolescents, 1999-2010. JAMA. 2012; 307(5): 483-490. https://doi.org/10.1001/jama.2012.40

2. Reilly J, Kelly J. Long-term impact of overweight and obesity in childhood and adolescence on morbidity and premature mortality in adulthood: systematic review. Int. J. Obes. (Lond). 2010; 35(7): 891-898. https://doi.org/10.1038/ijo.2010.222

3. Larson N, Ward DS, Neelon SB, Story M. What role can child-care settings play in obesity prevention? A review of the evidence and call for research efforts. J. Am. Diet. Assoc. 2011; 111(9): 1343-1362. https://doi.org/10.1016/j.jada.2011.06.007

4. Charzewska J., editor. Rekomendacje dla realizatorów żywienia z zakresu zasad prawidłowego żywienia dzieci w przedszkolach. Warszawa: Instytut Żywności i Żywienia; 2011 (in Polish).

5. Dev DA, McBride BA. Academy of Nutrition and Dietetics benchmarks for nutrition in child care 2011: are child-care providers across contexts meeting recommendations? J. Acad. Nutr. Diet. 2013; 113: 1346-1353. https://doi: 10.1016/j.jand.2013.05.023

6. Central Statistical Office [Internet]. Warsaw: Central Statistical Office; 2016. Education in 2015/2016 school year [cited 2017 Oct 20]. Available from: http://stat.gov.pl/en/topics/education/education/education-inthe-school-year-20152016,1,12.html

7. Benjamin Neelon SE, Briley ME. Position of the American Dietetic Association: benchmarks for nutrition in child care. J. Am. Diet. Assoc. 2011; 111(4): 607-615. https://doi.org/10.1016/j.jada.2011.02.016

8. Erinosho TO, Ball SC, Hanson PP, Vaughn AE, Ward DS. Assessing foods offered to children at child-care centers using the healthy eating index-2005. J. Acad. Nutr. Diet. 2013; 113: 1084-1089. https://doi.org/10.1016/j.jand.2013.04.026

9. Jarosz M., editor. Normy żywienia dla populacji polskiej - nowelizacja. Warszawa: Wyd. IŻŻ; 2012 (in Polish).

10. Mamo, tato, wolę wodę! [Internet]. Żywiec Zdrój S.A.; 2013. 0 programie [cited 2017 Nov]. Available from: https://www.wolewode.pl/dla-rodzicow/o-programie.html (in Polish).

11. Kozioł-Kozakowska A, Piórecka B, Schlegel-Zawadzka M. Program edukacji żywieniowej dla dzieci w wieku przedszkolnym i ich rodziców realizowany w Krakowie. Studia Medyczne. 2008; 11: 65-69 (in Polish).

12. Zdrowo jemy, zdrowo rośniemy [Internet]. Warszawa: Fundacja Rozwoju Dzieci im. Jana Amosa Komeńskiego; 2014 [cited Nov 2017]. Available from: http://www.zdrowojemy.info (in Polish).

13. Myszkowska-Ryciak J, Harton A. Do preschools offer healthy beverages to children? A nationwide study in Poland. Nutrients. 2017; 9: 1167. https://doi.org/10.3390/nu9111167

14. Addessi E, Galloway AT, Visalberghi E, Birch LL. Specific social influences on the acceptance of novel foods in 2-5-year-old children. Appetite. 2005; 45(3): 264-271. https://doi.org/10.1016/j.appet.2005.07.007

15. Gubbels J, Kremers S, Stafleu A, Dagnelie P, De Vries N, Thijs C. Childcare environment and dietary intake of 2-and 3-year-old children. J. Hum. Nutr. Diet. 2010; 23(1): 97-101.

https://doi.org/10.1111/j.1365-277X.2009.01022.x 
16. Regulation of the Minister of Health of 26 August 2015 on groups of foodstuffs for sale to children and young people in the units of the education system and the requirements to be met by the foods used in the context of public nutrition of children and young people in those units. Journal of Laws, item 1256 (in Polish).

17. Regulation of the Minister of Health of 26 July 2016 on groups of foodstuffs for sale to children and young people in the units of the education system and the requirements to be met by the foods used in the context of public nutrition of children and young people in those units. Journal of Laws, item 1154 (in Polish).

18. Weker H, Barańska M., editors. Kompleksowa ocena sposobu żywienia dzieci w wieku 13-36 miesięcy w Polsce - wyniki badań 2010-2011. Warszawa: Fundacja Nutricia; 2011 (in Polish).

19. de Ruyter JC, Olthof MR, Seidell JC, Katan MB. A trial of sugar-free or sugar-sweetened beverages and body weight in children. N. Engl. J. Med. 2012; 367: 1397-406. https://doi.org/10.1056/NEJMoa1203034

20. Ebbeling CB, Feldman HA, Chomitz VR, Antonelli TA, Gortmaker SL, Osganian SK, et al. A randomized trial of sugar-sweetened beverages and adolescent body weight. N. Engl. J. Med. 2012; 367: 1407-16. https://doi.org/10.1056/NEJMoa1203388

21. World Health Organization. Guideline: sugars intake for adults and children. Geneva: World Health Organization; 2015.

22. Ramsay SA, Branen LJ, Fletcher J, Price E, Johnson SL, Sigman-Grant M. “Are you done?" Child care providers' verbal communication at mealtimes that reinforce or hinder children's internal cues of hunger and satiation. J. Nutr. Educ. Behav. 2010; 42(4): 265-270. https://doi.org/10.1016/j.jneb.2009.07.002

23. Johnson SL. Improving preschoolers' self-regulation of energy intake. Pediatrics. 2000; 106(6): 1429. https://doi.org/10.1542/peds.106.6.1429

24. Myszkowska-Ryciak J, Harton A. Ocena realizacji norm i zaleceń żywieniowych w wybranych placówkach przedszkolnych z terenu Krakowa. In: Gromadzka-Ostrowska J., editor. Metabolizm i fizjologia jako podstawy postępowania dietetycznego. Warszawa: Wydawnictwo SGGW; 2016. p. 357-69 (in Polish).

25. Myszkowska-Ryciak J, Harton A. Ocena realizacji norm i zaleceń żywieniowych w wybranych placówkach przedszkolnych z terenu Poznania. Probl. Hig. Epidemiol. 2018; 99(1): 7-11 (in Polish).

26. Weker H, Hamułka J, Więch M, Głowacka K. Analysis of nutrition of children in Warsaw day nurseries in view of current recommendations. J. Pre-Clin. Res. 2010; 4(1): 63-67.

27. Harton A, Myszkowska-Ryciak J. Wpływ edukacji żywieniowej na realizację zaleceń modelowej racji pokarmowej w wybranych żłobkach - wyniki wstępne. Stand. Med. Pediatr. 2016; 13: 567-73 (in Polish).

28. Harton A, Myszkowska-Ryciak J. Wpływ edukacji żywieniowej personelu na zawartość realizację norm na składniki mineralne w jadłospisach dekadowych wybranych żłobków z Warszawy. In: Gromadzka-Ostrowska J., editor. Metabolizm i fizjologia jako podstawy postępowania dietetycznego. Warszawa: Wydawnictwo SGGW; 2016. p. 308-23 (in Polish).

29. Merkiel S, Chalcarz W. Preschool diets in children from Piła, Poland, require urgent intervention as implied by high risk of nutrient inadequacies. J. Health Popul. Nutr. 2016; 35: 11. https://doi.org/10.1186/s41043-016-0050-4

30. Zalewska M, Jamiołkowski J, Genowska A, Białokoz-Kalinowska I, Daszuta-Zalewska A, Maciorkowska E. Change in knowledge of kindergarten employees participating in the course "Diet full of life" in the field of children's nutrition, as assessed by generalized estimating equations. Studies in Logic, Grammar and Rhetoric. 2016; 47(60): 113-28. https://doi.org/10.1515/slgr-2016-0050 